\title{
FISHERIES AND THE BY-CATCH OF THE SHRIMP BEACH SEINE IN EL-MALAHA LAKE, PORT- SAID, EGYPT
}

\author{
Ashraf I. Ahmed and Mohammad E. El-Mor \\ Marine Science Department, Faculty of Science, Suez Canal University, \\ Ismailia, Egypt \\ E-mail: ashrafibrahim2002@ yahoo.com
}

Keywords: El-Malaha Lake, Port-Said, fisheries, shrimp beach seine, by-catch

\section{ABSTRCT}

The present study indicated that 400 fishermen work during the fishing 1 season in El-Malaha Lake; most of them are from Port-Said. The average annual catch in the period from 1995 to 2004 constituted 149.817 tones/year. During 2003/2004 the catch composition was represented by 16 species belong to 11 families; Sparidae and Mugilidae were the most dominants families, represented by $44.66 \%$ and $26.74 \%$ respectively and the catch per unit boat was $282.3 \mathrm{Kg}$ / boat.

The by - catch of the beach seine operating in El-Malaha Lake during the period from July 2003 till June 2004 was analyzed. The amount of by-catch was about 3-6 Kg per haul (30\%) of the total landing beach seine catches. The by - catch was classified into three groups; juveniles of the commercial fishes (98.72\%), low value small size fish species (1\%) and $0.28 \%$ of non edible trash fish. The catch composition was classified into 25 species belonging to 13 families. Among these 7 species are Red Sea origin, whereas 18 species are Mediterranean Sea origin. The most dominant species were Siganus rivulatus, Sardinella aurita, Sardinella maderensis, Rhabdosargus haffara, Aleps djedaba and Solea vulgaris constituting $65.5 \%$ of the total by - catch.

\section{INTRODUCTION}

El-El-Malaha Lake considered a hyper-saline lagoon, lies in the northwestern part of Sinai Peninsula, between $31^{\circ} 7^{\prime}$ and $31^{\circ} 15^{\prime}$ Latitude and $32^{\circ} 20^{\prime}$ and $32^{\circ} 30^{\prime}$ Longitude (Map 1). It is triangular shaped water body, stretching $14 \mathrm{Km}$ south along the Suez Canal and $30 \mathrm{Km}$ east along the coastal line of the Mediterranean Sea. The surface area decreased 
from 33,000 to 21,000 feddans after 1976 conflict, as the result of the construction of a road between Rommana and kilometer 19th on the Suez Canal.

In 1984 the new Lake has been reconstructed east the old ElMalaha by the surface area 10,000 feddans which, recently reduced to 5,500 feddans to build the free zone Suez Canal east. Water depth in the lake varies from 30 to $120 \mathrm{~cm}$; the deepest parts being in the central region. El-Malaha Lake consists of two shallow hyper-saline lagoons, the size and shape of which are variable; they reach the maximum size during winter and become nearly dry in summer season. The lagoons are connected to the Mediterranean Sea via Boughaze El- Kalaa (eastern lagoon) and Boughaze El-Malaha (western lagoon). The two lagoons are separated from the Mediterranean Sea by a sandbar that varies in width between 100 to $500 \mathrm{~m}$. There is no freshwater influx in the lake ( Hanafy et al., 1996).

Many authors studied the hydrographic conditions and sediments of El-Malaha Lake. A wide variation in the salinity was reported, which ranged from 55.9\%o in winter and 74.9 \%o in summer. Water temperature ranged between $12^{\circ} \mathrm{C}$ in winter and $34^{\circ} \mathrm{C}$ in summer. Variations in physico-chemical parameters of the El-Malaha Lake water are related mainly to the shallowness and sheltering conditions, rate of water exchange, salt deposition and evaporation (El-Deek ,1979). El-Sabrouti et al. (1989) defined the sediment texture in El-Malaha Lake and he concluded that the northern part is covered by clay silt sediments, whereas western sectors are silty clay and the central area is covered by more than one type of sediments.

El-Malaha Lake plays an important role as fishing ground for many commercial uncontaminated fish species of Port-Said catch and as a nursery ground for juveniles of many marine fish. It serves as the habitat for migratory birds. El-Malaha Lake serves as one of the most important wetland in Egypt for the water birds, and holds some of the greatest densities and number of both wintering and breeding water bird in the country ( Hanafy et al., 1996).

Many studies have been conducted on the impact of the beach seine on coastal habitats, bays and lakes which used as a nursery for many commercial fishes and invertebrates; like those on the eastern Alexandria harbor (Al-Sayes et al., 1981), Sharm El Moyia Bay and mangrove habitats in Sharm El-Sheikh (Ahmed, 1992), Abu-Kair Bay (Faltas, 1997), Port Said fishing harbor (El-Mor, 2002), Bitter Lakes (Ahmed et al., 2002) and Lake Timsah (Ahmed, 2005). 
However, no previous work in this respect has been done on El-Malaha Lake, So the present study deals with fisheries status of El-Malaha Lake and species composition, size structure and abundance of the by - catch of the shrimp beach seine.

\section{MATERIALS AND METHODS}

Fisheries data of El-Malaha Lake have been collected from the General Authority for Development of Fish Resources (GADFR, 19952004) and Northern Fisheries Company (NFC, 1995-2004), Port-Said Office. Data about fish catch, fishing gears, fishing boats and number of fishermen in El-Malaha Lake during the period from 1995 to 2004 were obtained and analyzed to evaluate the fisheries status of the study area.

Catch of shrimp beach seine (effective all time) has been collected monthly (3-6 Kg / haul) in the period from July 2003 till June 2004. In the laboratory, fish samples were sorted and identified to the species level using the available literature (Hureau and Monod, 1973; Randal, 1983; Ben-Tuvia, 1986 ; Smith and Heemstra, 1986; Whitehead et al., 1986). The total length of each fish was measured to the nearest $\mathrm{mm}$, from the tip of snout to the end of the caudal fin, while the total weight was measured to the nearest gm.

\section{I- Fisheries of El-Malaha Lake \\ Fishermen, fishing gears and boats}

\section{RESULTS}

Four hundred fishermen work during the fishing season in ElMalaha Lake, most of them are local fishermen (70 \% from Port-Said) and the others are visitor's fishermen (30\% from El-Matria and Domiatta).The major fishermen; about 62\% are uneducated, whereas 33\% are moderately educated and 5\% are highly educated. They are classified based on the type of gears used; some of them (65\%) use gill and trammel nets, whereas the others use sandra net (28\%) for mullet catch and the rest use the shrimp beach seine (7\%).

All the fishermen usually use a small, wooden un-motorized boat throughout the lake. The boat is about three meters in length and $120 \mathrm{~cm}$ in width. The boat has a flat bottom (there is no keel) to move in the shallow water easily. Fishermen use medra (ores) instead of the ordinary ores. 


\section{The annual variations in catch}

The annual landing catches of El-Malaha Lake in the last 9 years have been represented in Table (1). According to the regulations of GADFR and NFC, the fishing seasons in the period from 1995/1996 to 2002 / 2003 varied from August till February whereas, in 2003 / 2004 the fishing season was extended to the whole year. The maximum yield of ElMalaha Lake has been recorded in the fishing season 1996/1997 (207,411 tonnes) then decreased to reach its minimum yield during $2001(67,296$ tonnes), then the yield sharply increased (195,434 tonnes) in 02/03 and decreased in 2003/2004 to 139,992 tonnes.

\section{Catch composition}

The total catch in El-Malaha Lake in the fishing seasons 2003/2004 was amounted for 139,992 tonnes. The catch composition during this fishing season was represented by 16 species belonging to 11 families (Table 2). The most dominant families were Sparidae and Mugilidae constituting $44.66 \%$ and $26.74 \%$ respectively. Sparidae was represented only by Sparus auratus, whereas Mugilidae was represented by the major species; Mugil cephalus (26.16\%) and the minor ones were Liza carinata and Liza aurita ( $0.55 \%$ and $0.03 \%$ respectively). Family Soleidae was constituted $7.84 \%$ of the total catch, represented by one species (Solea solea), whereas Serranidae was amounted for $6.88 \%$; represented by three species; Dicentrarchus labrex (5.54\%), D. punctatus $(1.33 \%)$ and Epinephelus malabaricus (0.01\%). The minor species varied from $1.46 \%$ for Aregyrosomus regius to $0.09 \%$ for Terapon puta.

The trash catch of shrimp beach seine was constituted $2.91 \%$ of the total catch in 2003/2004, whereas the invertebrates catch varied from $6.58 \%$ of the total catch (Protunus plegicus) to $0.51 \%$ (Penaeus japonicus).

\section{Monthly variations in catch}

The monthly variations in the most dominant species were found to vary greatly from one month to anther (Table 3). Generally, there was influx of the most dominant species; Sparus auratus , Mugil cephalus , Solea solea, Portunus pelagicus in late summer, autumn months and early winter, recording the maximal catch of all species in September except in S. auratus in August and $P$. pelagicus in July. The minimum catch of S.auratus was in January, M. cephalus in May, S. solea in April, $P$. pelagicus in December, whereas D. labrax in July. The duration of appearence of the most dominant species in catch varied from seven months in $P$. pelagicus to eleven months in $S$. solea. 


\section{Catch per unit effort (C.P.U.E.)}

The total catch observed during the fishing season 2003/2004 was $139992 \mathrm{Kg}$, while the total number of working boats was 496 with monthly average of about 41 boats. The crew is about 3 fishermen for boat (Table 4).

Regardless to the type of the fishing gears, fish species and even the time of fishing; the average CPUE was about $282.3 \mathrm{~kg} /$ boat/ month. The catch / boat recorded its highest value $(538.65 \mathrm{~kg} /$ boat $)$ in September, whereas the minimal value (2.0 kg /boat) was in February (Table 4).

\section{II- By-catch of the shrimp beach seine \\ Species composition and overall abundance}

A total of 2511 fish individuals have been collected in one year by the shrimp beach seine from July 2003 to June 2004. The by-catch can be classified into three main categories; juveniles of commercial fish species, low value small sized fish and non-edible fish species.

Juveniles of the commercial fish species constituted $98.72 \%$ of the total by - catch which were represented by 21 species belonging to 9 families. Siganidae which is represented by Siganus rivulatus and Clupeidae which is represented by four species; Sardinella aurita, $S$. maderensis, Sardina pilichardus and Dussmieria acuta were constituted by $23.06 \%$ and $20.11 \%$ of the total by-catch respectively. The overall abundance of Sparidae (Rhabdosargus haffara, Diplodus annularis, D. vulgaris, D. sargus and Lithognathus mormyrus), Carngidae (Alepes djedaba), and Mugilidae (Liza carinata, L .ramada, L. aurita, L. saliens and Mugil cephalus) varied from $14.45 \%$ to $11.04 \%$. The minor families such as Soleidae, Teraponidae and Mullidae and Serranidae ranged between $6.77 \%$ and $1 \%$ of the total by-catch (Table 5).

The low-value fish species constituted $1 \%$ of the total by-catch and was represented by two species; Gobius paganellus and Engraulis encrasicolus belonging to two families; Gobiidae and Engraulidae respectively (Table 5).

The non-edible species constituted $0.28 \%$ of the total by-catch and was represented by Parablennius incognitus (0.16\%) and Apogon taeniatus (0.12\%) (Table 5).

The origin of the by catch fish species is represented in Table (5). Seven species represented $49.11 \%$ of all species caught by the shrimp beach seine were Red Sea origin, whereas 18 species were Mediterranean Sea origin and constituting 50.89\%. 


\section{Monthly relative abundance and size composition}

The juvenile commercial fishes of Siganus rivulatus (23.06\%), Sardinella aurita (11.47\%), S. maderensis (6.57\%), Rhabdosargus haffara (5.69\%), Alepes djedaba (11.95\%) and Solea vulgaris (6.77\%) constituted $65.51 \%$ of the total by-catch (Table 5).

Juveniles of $S$. rivulatus in the area of study were obtained during four months from October to January. They varied in length between 2.5 and $5.9 \mathrm{~cm}$ with an average weight of $2.62 \mathrm{gm}$. The recruitment took place in October (Table 6).

Specimens $S$. aurita were recorded in the by-catch in the period from April to July and varied in their total length from $2.5 \mathrm{~cm}$ (in April where the recruitment took place) to $4.8 \mathrm{~cm}$ ( in July). Their highest occurrence in the catch has been recorded in May (25.7\%), whereas the lowest was in July (12.4\%). The recruitment of $S$. maderensis was in September where the smallest juvenile, reached $2.6 \mathrm{~cm}$ in total length and attained the lowest abundance (15.5\%) then increased in size, reaching the maximum value in the nursery area $(4.4 \mathrm{~cm})$ in December. Their highest relative abundance attained in November (33.8. \%). The first sign of appearance of $R$. haffara was in January, where the recruitment took place; the smallest size and average weight attained were $2.6 \mathrm{~cm}$ and $3.45 \mathrm{gm}$ respectively, then the size and average weight increased in the next month reaching their maximum values in March $(5.1 \mathrm{~cm}$ and $5.46 \mathrm{gm}$ respectively). Their monthly relative abundance varied from $33.2 \%$ in January to $34.7 \%$ in February. The occurrence of Alepes djedaba in the study area extended to four months from July; where the smallest length and weight $(2.1 \mathrm{~cm}$ and $1.45 \mathrm{gm}$ respectively) to October; where the maximum length and weight may occur $(5.1 \mathrm{~cm}$ and $3.68 \mathrm{gm}$ respectively ). Specimens of $S$. vulgaris varied from $3.4 \mathrm{~cm}$ in total length and $3.74 \mathrm{gm}$ (in average weight) in March to $6.6 \mathrm{~cm}$ and $5.11 \mathrm{gm}$ in May (Table 6).

\section{DISCUSSION}

Widespread interest in the environmental impact of fishing and its ecosystem effects has stimulated intense research in the last 15 years. It is not just the fish populations that need protecting but also the environment that supports them. A number of recent studies have established that intensive fishing dramatically impacts all levels of biological organisation of marine life, i.e. population, communities and the ecosystem. 
Fishing in the Mediterranean has increased by about 48\% since 1970 with high exploitation of both bottom-living (demersal) and big pelagic stocks, e.g. tuna and swordfish. The overall upward catch trends for many species registered up until about a decade ago suggest that perhaps recruitment of young fish has been converted unintentionally despite intensive fishery for demersal and a lack of quota control. However, shortterm trends over the last ten years now reflect a general picture of full-toover exploitation for most demersal and shell fish populations (Carbonell et al., 1998; Bertrand et al., 2002 ; Gianni, 2004).

Many authors have reported the damage caused by shrimp beach seine which affects badly on the fish stock resources of the Suez Canal Lakes (Ahmed et al., 2002 ; Ahmed, 2005), bays and beaches of Egyptian Mediterranean Coasts (Al-Sayes et al., 1981; Faltas, 1997; Ahmed, 1992; El-Mor, 2002 ; El-Mor et al., 2002) which are considered as the nursery grounds for many juveniles of the commercial fishes. Intensification of these activities can perform undesirable collapse of fish stocks due to the capture of juveniles of commercial species before sexual maturation.

In the present work, the by- catch of the shrimp beach seine constituted $2.91 \%$ of the total catch in the El-Malaha Lake which is considered the nursery ground for many commercial fish species. Juveniles of the commercial fish species were constituted $98.72 \%$ of the total by-catch and their major families were Siganidae, Clupeidae, Sparidae, Carngidae and Mugilidae, whereas the minor families were Solidae, Teraponidae, Mullidae and Serranidae which ranged between $6.77 \%$ and $1 \%$ of total by-catch. This in agreement with the findings of El-Mor (2002) who recorded that the major families in the by-catch of shrimp beach seine were Siganidae, Clupeidae, Sparidae and Mugilidae from Port Said fishing harbour.

The by-catch of the shrimp beach seine in El-Malaha Lake was represented by 25 species belonging to 13 families and $49.11 \%$ of all species were of Red Sea origin. This result revealed the presence of poor species richness in the study area. Faltas (1997) recorded 41 species belonging to 25 families and the Red Sea immigrant species constituted $12 \%$ of the by-catch of the shrimp beach seine in Abu-Kir Bay, Alexandria. El-Mor (2002) recorded 42 species belonging to 24 families and 17 species represented 53.4\% Red Sea immigrant species of the bycatch in Port Said fishing harbor. The differences in fish species richness may be attributed to the way different sites, methods, and seasons of collection. 
In the present work, the juvenile commercial fishes of Siganus rivulatus, Sardinella aurita, S. maderensis, Rhabdosargus haffara, Alepes djedaba and Solea vulgaris constituted $65.51 \%$ of the total shrimp beach seine by-catch. Juveniles of Signus rivulatus occurred in the area of study for four months from October till January and the recruitment took place in October. S. aurita recorded in the by-catch in the period from April to July, whereas, the recruitment of $S$. maderensis was in September till December. The first sign of appearance of $R$. haffara was in January in which the recruitment took place, then the size and average weight increased in the next month reaching the maximum size and average weight in March. The occurrence of Alepes djedaba in the area of study extended to four months from July, in which the smallest length and weight to the maximum length and weight in October. Juveniles of $S$. vulgaris recruited from March till May.

This in agreement with the spawning seasons of the above mentioned species, where the spawning season for $S$. rivulatus was in the period from June to September (Hussein, 1986), January to March for Sardinella. aurita (Ben-Tuvia, 1960; Rifaat, 1960; El-Rashidy, 1987), July till September for Sardinella maderensis (Whitehead, 1965), December for $R$. haffara (Al-Oraimi, 1996), May and July for A. djedaba (Sergio et al., 1997) and winter months for Solea vulgaris (El-Ghrabawy, 1977; El-Etreby et al., 1993).

\section{REFERENCES}

Ahmed, A. I. (1992). Ecological and biological studies on juvenile fishes from South Sinai, Red sea. M.Sc. Thesis, Faculty of Sci., Suez Canal Univ., Egypt.

Ahmed, A. I.; El-Mor, M.; Gabar, H. and El-Shafai, A. (2002). Species composition and abundance of juvenile fishes in Great Bitter Lakes, Suez Canal, Egypt. J. Aquat. Biol. \& Fish., 8 (3): 195211.

Ahmed, A. I. (2005). The by-catch of the shrimp beach seine in Lake Timsah, Suez Canal. Egypt. J. Aquat. Biol \& Fish., 9 (4): 45-61. 
Al- Oraimi, A. M. (1996). Fisheries and biological studies on Rhabdosargus haffara (family: Sparidae) in Suez Canal. M.Sc. Thesis, Fac. Sci., Suez Canal Univ., ARE.

Al-Sayes, A. A.; Hashem, M. T. and Soliman, I. A. (1981). The beach seine fishery of the Eastern Harbor, Alexandria. Bull. Inst. Oceanogr. \& Fish., ARE, 7 (3): 323-342.

Ben-Tuvia A. (1960). Synopsis of biological data on Sardinella aurita of the Mediterranean Sea and other waters. In: Proc. World Sci. Meet. Biol. Sardines \& Related sp. FAO, species synopsis 9 : 287-312.

Ben-Tuvia, A. (1986). Mugilidae. In: Fishes of the North-eastern Atlantic and the Mediterranean. (Whitehead, P.J.P.; Bauchot, M.L.; Hureaue, J.C.; Nielsen, J. and Tortonese, E. (eds.), UNESCO, pp, 1197-1204.

Bertrand, J. A.; Gil De Sola, L. and Papaconstantinou, C. (2002). The general specifications of the MEDITS surveys. In: Mediterranean Marine Demersal Resources. The MEDITS International Trawl Survey (1994-1999). Scientia Marina. 66 (Suppl.2), pp. 9-17.

Carbonell, A.; Martin, P. and De Ranieri, A. (1998). Discards of the western Mediterranean trawl fleets. In: Rapport du 35 eme Congres de la Commission.

El-Deek, M. S. (1979). Physical and chemical variations of Port-Fouad lagoon, Egypt. M.Sc. Thesis, Alexandria University.

El-Etreby, S. G.; El-Gamal, F. and Mahmoud, M. (1993). Biological studies on Solea solea (Linnaeus, 1758) in Lake Bardawil, North Sinai II- Reproductive biology. Bull., Fac. Sci., Zagazig Univ., 15 (1): 551-563. 
El-Ghrabawy M. M. (1977). Biological studies on Sole in the region of Abu-Kir Bay. M.Sc. Thesis. Faculty of Sci., Alexandria Univ., ARE.

El-Mor M. (2002). Ecological and Biological studies on juvenile commercial fishes from Port-Said coasts. Ph.D., Fac. Sci., Suez Canal Univ., Egypt.

El-Mor, M.; El-Etreby, S. and Sapota, M. (2002). Species composition and structure of beach seine by-catches in Port-Said fishing harbor, Egypt. Oceanological Studies, 31 (3-4 ) : 43.

El-Rashidy, H. H. (1987). Ichthyplankton of the South Eastern Mediterranean Sea off the Egyptian Coast. M.Sc. Thesis, Faculty of science, Alex. Univ., Egypt.

El-Sabrouti,M.; Saad, M.A.H.; Nawar, A. H. and Deghedy E.M. (1989). Studies on the bottom sediments of Port-Fouad Lagoon near PortSaid, Egypt. Com. Sci. Dev. Res., 25:61-93.

Faltas, S. N.( 1997). Analyses of beach seine catch in Abu-Kir Bay (Egypt). Bull. Nat. Inst. Oceanogr. and Fish., A.R.E., 23: 69-82.

GADFR (1995-2004). Annual reports of fish catch of the General Authority of Development of Fish Resources.

Gianni, M. (2004). Sea bed trawling, the greatest threat to deep-sea biodiversity. Fisheries Research. 52: 181-195.

Hanafy, M. H.; Gab-Allah, A. A.; Kotob,M. M.; Ahmed, A. I. and Amer, M.A. (1996). Report on environmental description and ecological imortance of the coastal region between Port Said and Tina Bay.

Hureau, J. C. and Monod, T. H. (1973). Check list of the fishes of the North Eastern Atlantic and of the Mediterranean. UNESCOClofnam I: 357-358. 
Hussein, A. (1986). Timing of spawning and fecundity of Mediterranean Siganus rivulatus Forsk. Bull. Inst. Oceanogr \& fish. , A.R.E., 12: 175-186.

NFC (1995-2004). Annual reports of fish catch of the Northern Fisheries Company, Port Said.

Randal, J. E. (1983). Red Sea Reef Fishes. IMMEL Publishing Co. London, $192 \mathrm{pp}$.

Rifaat, A. (1960). Sardine fisheries in United Arab Republic (Southern region). In: Proc. World Sci. Meet. Biol. Sardines \& Related sp., FAO, 3: 1205-1212.

Sergio, M. H. F. A.; Soliman, V. S.; Bola, E. B. and Bustamante, F. B. (1997). Aspects of the reproductive biology of trawl-caught fishes in San Miguel Bay. P. 65-90. In: Soliman, V. S. and Dioneda,R. D. (eds.) Capture Fisheries Assessment of San Miguel Bay, Post-Resource and Ecological Assessment of San Miguel Bay, phil, Vol. 1 BFAR, Fish. Sect. Prog. and Bicol Univ. Coll. of Fish. SMB Post. REA Tech. Rep 1,90pp.

Smith, M. M. and Heemstra, P. C. (1986). Smith’s Sea Fishes. SprengerVerlag Co., 104 pp.

Whitehead, P. J. P. (1965). A review of the Elopid and Clupeoid fishes of the Red Sea and adjacent regions, Bull. Brit. Mus. Nat. Hist. (Zool.), 12(7):225-281.

Whitehead, P. J. P.; Bauchot M.L.; Hureau J. C.; Nielsen, J. and Tortonese, E.,(1986). Fishes of the North- Eastern Atlantic and Mediterranean. UNESCO, 1, 2 and 3: 1473 pp. 


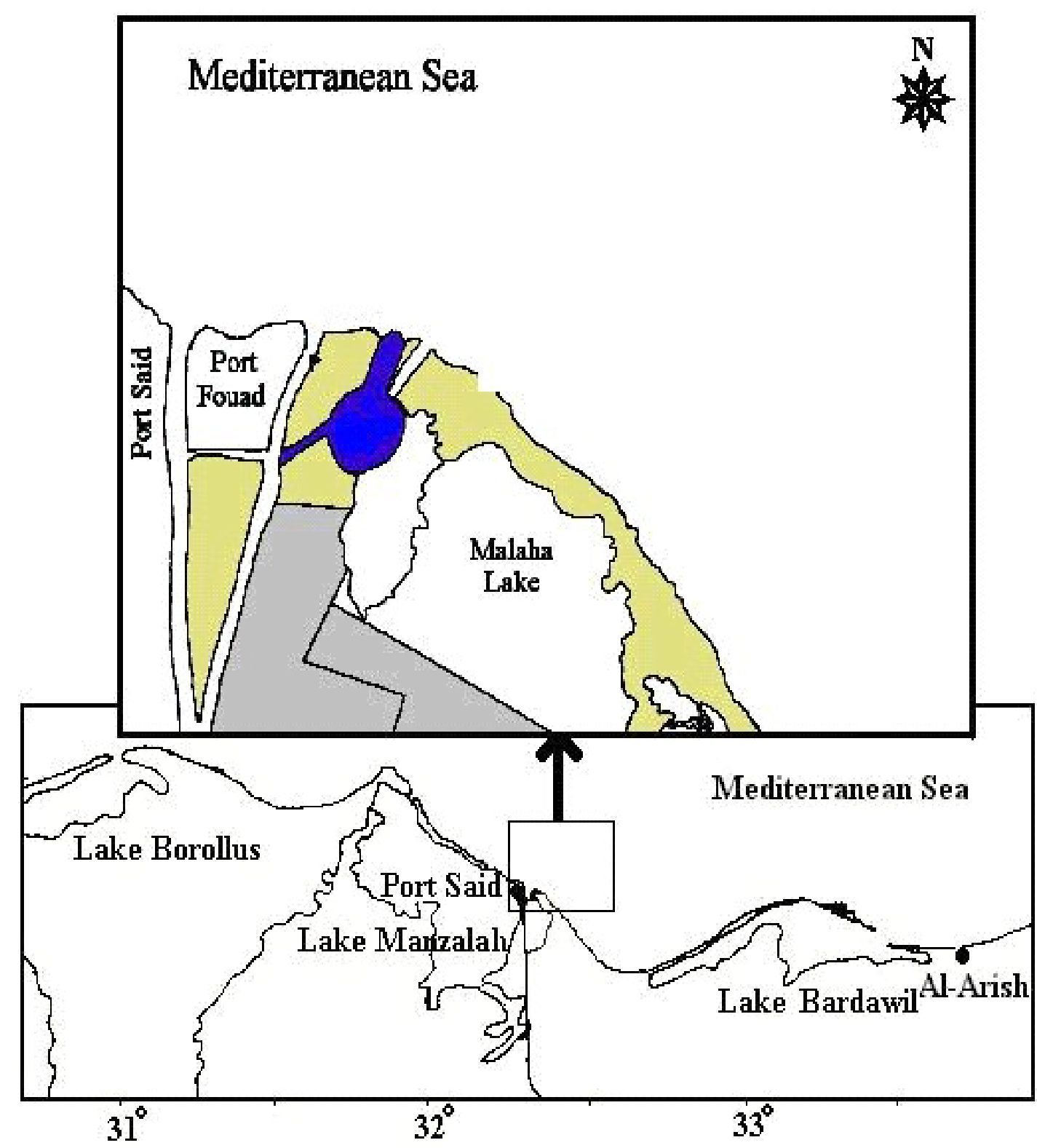

Map (1): El-Malaha Lake 